\title{
Biomass Not Linked to Perennial Grass Mortality Following Severe Wildfire in the Southern High Plains
}

\author{
Sandra Rideout-Hanzak, ${ }^{1}$ David B. Wester, ${ }^{2}$ Carlton M. Britton, ${ }^{2}$ and Heather Whitlaw ${ }^{3}$
}

Authors are ${ }^{1}$ Assistant Professor, Department of Animal and Wildlife Sciences, and Caesar Kleberg Wildlife Research Institute, Texas Aઐ M UniversityKingsville, Kingsville, TX 78363, USA; ${ }^{2}$ Professor, Department of Natural Resources Management, Texas Tech University, Lubbock, TX 79409, USA; and ${ }^{3}$ Southern Plains Coordinator, US Fish and Wildlife Service, Lubbock, TX 79409, USA.

\begin{abstract}
In March 2006 the East Amarillo Complex (EAC) wildfires burned over 367000 ha of short and mixed grass prairie of the southern High Plains, USA. We studied EAC wildfire effects on perennial grass mortality and peak standing crop on Deep Hardland and Mixedland Slopes ecological sites. Deep Hardlands were dominated by blue grama (Bouteloua gracilis H.B.K. [Griffiths]) and buffalograss (Buchloe dactyloides [Nutt.] Engelm.); common species on Mixedland Slopes were little bluestem (Schizachyrium scoparium [Michx.] Nash.) and sideoats grama (Bouteloua curtipendula [Michx.] Torr.) with scattered sand sagebrush (Artemisia filifolia Torr.) sometimes present. We hypothesized that perennial grass mortality would increase and standing crop would decrease following severe wildfire, and that these responses would be greater than documented prescribed fire effects. Frequency of perennial grass mortality was higher on both sites in burned areas than nonburned areas through three growing seasons following wildfire; however, standing crop was minimally affected. Results suggest that post-wildfire management to ameliorate wildfire effects is not necessary, and that wildfire effects in this area of the southern High Plains are similar to prescribed fire effects.
\end{abstract}

\section{Resumen}

En Marzo de 2006 los incendios del Complejo del Este de Amarillo (CEA) quemaron más de 367.000 ha de estepas de pastos cortos y mixtos del sur de las Altas Planicies de EE.UU. Estudiamos los efectos del incendio del CEA sobre la mortalidad de pastos perennes y la biomasa total acumulada en dos sitios ecológicos denominados Deep Hardland (DH) y Mixedland Slopes (MS). Las especies dominantes en el sitio DH fueron Bouteloua gracilis H.B.K. [Griffiths] y Buchloe dactyloides, mientras que las especies comunes en el sitio MS fueron Schizachyrium scoparium [Michx.] Nash.y Bouteloua curtipendula [Michx.] Torr. con la presencia esporádica de individuos de Artemisia filifolia Torr. Nuestra hipótesis predijo que los incendios severos aumentarían la mortalidad de pastos perennes y disminuirían la biomasa en pie y que dichas respuestas serian mayores a las documentadas en quemas prescriptas. En ambos sitios, la frecuencia de mortalidad de pastos perennes fue mayor en áreas quemadas que en áreas no quemadas a lo largo de tres estaciones de crecimiento posterior al incendio; no obstante, la biomasa en pie fue mínimamente afectada. Los resultados sugieren que el manejo post-incendio tendiente a atenuar los efectos del mismo no es necesario, y que los efectos de los incendios en esta región sur de las Altas Planicies es similar a la de las quemas prescriptas.

Key Words: East Amarillo Complex, fire ecology, perennial grasses, plant mortality, post-fire management, primary production, wildfire

\section{INTRODUCTION}

Fire is an important factor that not only affected the historical development and expansion of $\mathrm{C}_{4}$-dominated North American grasslands (Axelrod 1985; Keeley and Rundel 2005; Stromberg 2005; Anderson 2006), but it also currently affects their structure, function, and composition (e.g., Wright and Bailey

Research was funded by the Natural Resources Conservation Service for funding (Fish and Wildlife Conservation Grant, Agreement No. 69-7482-2843) and Texas Parks and Wildlife Dept (Interagency Contract No. 168976).

At the time of this research Sandra Rideout-Hanzak was Assistant Professor, Dept of Natural Resources Management, Texas Tech University, Lubbock, TX 79409, USA, and Heather Whitlaw was Wildlife Diversity Specialist, Texas Parks and Wildlife Dept, Lubbock, TX 79409, USA.

Correspondence: Sandra Rideout-Hanzak, Dept of Animal and Wildlife Sciences, and Caesar Kleberg Wildlife Research Institute, Texas A\&M University-Kingsville, Kingsville, TX 78363, USA. Email: sandra.rideout-hanzak@tamuk.edu

Manuscript received 23 April 2010; manuscript accepted 6 October 2010.
1982; Brockway et al. 2002; Anderson 2006). These plant communities and their species have evolved under regimes of frequent burning, and adaptations to fire are common. For example, structural features of grasses such as bud banks at or below ground level and rhizomes (Benson et al. 2004; Klimesova and Klimes 2007), and the production of surplus branch meristems (Doust 2007) are viewed as adaptations not only to grazers (Briske and Richards 1995; Dahl 1995) but also to fire (e.g., Anderson 2006).

Fire effects in grasslands have primarily been studied in the context of prescribed burning to control undesirable species (typically woody plants) and/or enhance herbaceous biomass production (e.g., Wright and Bailey 1982; Anderson 2006). Although there is considerable information on fire's effects on herbaceous production, less is known about perennial grass mortality. Because of this, statements such as "buffalograss and blue grama can tolerate fire" (Wright and Bailey 1982, p. 88) or "[buffalograss is] tolerant of summer fire" (Ansley and 
Castellano 2007, p. 154) might be interpreted to suggest that "fire does not kill" individuals of these species-in fact, statements such as these are almost always based on studies that did not measure plant mortality.

A more complete understanding of fire effects on perennial grasses should include multiple plant responses (e.g., biomass and mortality). We studied effects of the East Amarillo Complex (Texas) wildfires of 2006 with this research strategy. We hypothesized that perennial grass mortality would increase and standing crop would decrease following severe wildfire, and that these effects would be different than documented prescribed fire effects. The objective of this paper is to report effects of these wildfires on perennial grass mortality and grass production one, two, and three growing seasons after wildfire.

\section{METHODS}

\section{The East Amarillo Complex Wildfires}

In mid-March 2006, two separate wildfires known collectively as the East Amarillo Complex (EAC) burned during a 4-d period in the Texas Panhandle. The EAC was the culmination of weather conditions beginning with surplus rainfall during the fall of 2004 and ending with 8 mo of drought preceding the fires. The rate at which the fires spread in the first $24 \mathrm{~h}$ was unprecedented; the northernmost fire traveled approximately 45 miles in the first $9 \mathrm{~h}$ (Zane et al. 2006). This rate of spread was due in large part to extreme conditions (prolonged drought, low relative humidity, high winds). We have no flame length data; however, flame heights were reported to be $3.3 \mathrm{~m}$ (Zane et al. 2006), and the southernmost fire "jumped" Interstate 40 within minutes of ignition (crossing four lanes, a dividing median, and access roads on both sides). On the human scale the effects of the EAC were unsurpassed in Texas history: 12 human lives were lost, and over 89 structures and thousands of miles of fence were destroyed (Zane et al. 2006). There was total forage loss on 367000 ha of native rangeland, and over 4000 head of livestock perished. This wildfire complex was the largest in the contiguous 48 states since the 1988 Yellowstone fires (National Interagency Fire Center 2010). Its occurrence appears to extend to western grasslands the prediction (Westerling et al. 2006) that size and severity of forest wildfires in western states will increase as a result of anticipated global climate change.

\section{Study Sites}

Study sites were located on Deep Hardland (R077CY0022TX; US Department of Agriculture [USDA] 2008) and Mixedland Slopes (R077EY061TX; USDA 2008) ecological sites in Gray, Donley, and Roberts counties in the northern Panhandle of Texas. Study sites were located on privately owned ranches and were selected in August and September 2006 after the fires. We could not control for differences in land management practices.

Deep Hardlands are characterized by Pullman clay loams (fine, mixed, superactive, thermic Torrertic Paleustolls); a minor series in this site is the Estacado clay loam (fine-loamy, mixed superactive, thermic Aridic Paleustolls). Vegetation is dominated by blue grama (Bouteloua gracilis [Willd. ex Kunth] Lag. ex Griffiths) and buffalograss (Buchloe dactyloides [Nutt.] Engelm.), with smaller amounts of hairy grama (Bouteloua birsuta Lag.) and midgrasses such as sideoats grama (Bouteloua curtipendula [Michx.] Torr.). With respect to species composition and vegetation structure, Deep Hardlands are similar to typical shortgrass plains vegetation in climates with $<60 \mathrm{~cm}$ annual rainfall. The Mixedland Slopes typically have coarsertextured soils. They are characterized by Mobeetie fine sandy loams (coarse-loamy, mixed, superactive, thermic Aridic Haplustepts). Polar very gravelly sandy loams (loamy-skeletal, mixed, superactive, thermic Ustic Haplocalcids) and Potter gravelly loams (loamy-skeletal, carbonatic, thermic petronodic Ustic Haplocalcids), and slopes $>5 \%$ are also present. Many of these sites are mapped as soil complexes that also include heavier-textured soils. Common species include little bluestem (Schizachyrium scoparium [Michx.] Nash), sideoats grama, hairy grama, sand dropseed (Sporobolus cryptandrus [Torr.] A. Gray), Indiangrass (Sorghastrum nutans [L.] Nash), and sand bluestem (Andropogon gerardii var. paucipilus [Nash] Fern.); many areas support scattered sand sagebrush (Artemisia filifolia Torr.; USDA 2008). These sites have species composition and structural features typical of mixed-grass prairies.

\section{Field Methods}

Because we were studying wildfires, preburn data were not available. Our assessment of wildfire effects was therefore based on a comparison of burned areas and nearby nonburned areas that represented controls (see Wiens and Parker 1995). We established study plots in fall 2006 that were remeasured in late summer 2007 and 2008; in 2007 we established additional study plots that were measured only in 2007 and 2008. For both ecological sites we used a "matched-pairs" (Wiens and Parker 1995) design: plots in burned areas were paired with plots in similar nonburned areas. In 2006 we established five pairs of plots on Mixedland Slopes sites; an additional pair was added in 2007. Because of difficulty locating suitable landowners and study sites in late summer 2006, Deep Hardlands were sampled in 2006 with one burned plot and one nonburned plot; in 2007 we added five pairs of plots. In burned and nonburned sites at each study site an exclosure (9.75 $\mathrm{m} \times 9.75 \mathrm{~m} \times 1.5 \mathrm{~m})$ was constructed to exclude livestock; the lower $0.6 \mathrm{~m}$ of each exclosure was lined with poultry netting $(2.54-\mathrm{cm}$ mesh) to exclude smaller animals.

Mortality. In each study site we randomly located $501-\mathrm{m}^{2}$ nested quadrats (outside exclosures), with random relocation of quadrats each year of sampling. In each quadrat we recorded presence of dead perennial grasses in $0.25-\mathrm{m}^{2}, 0.50-\mathrm{m}^{2}$, and $1-\mathrm{m}^{2}$ subquadrats. Individual plants of bunchgrasses were clearly recognizable. For stoloniferous shortgrasses, our definition of an individual plant was similar to that used by Coffin and Lauenroth (1988) and Fair et al. (1999). We considered that a plant represented an individual if it was separated from other individuals by at least $5 \mathrm{~cm}$ and if there were no obvious underground connections to nearby plants (as determined by scraping beneath the soil surface with a pocket knife).

Herbaceous Biomass. Peak standing crop was estimated by harvesting aboveground herbaceous biomass by species in late summer, early autumn (Scurlock et al. 2002) to a $2.5-\mathrm{cm}$ height in two randomly located $0.25-\mathrm{m}^{2}$ quadrats in each exclosure (in 2007 four quadrats were harvested in each exclosure in the 

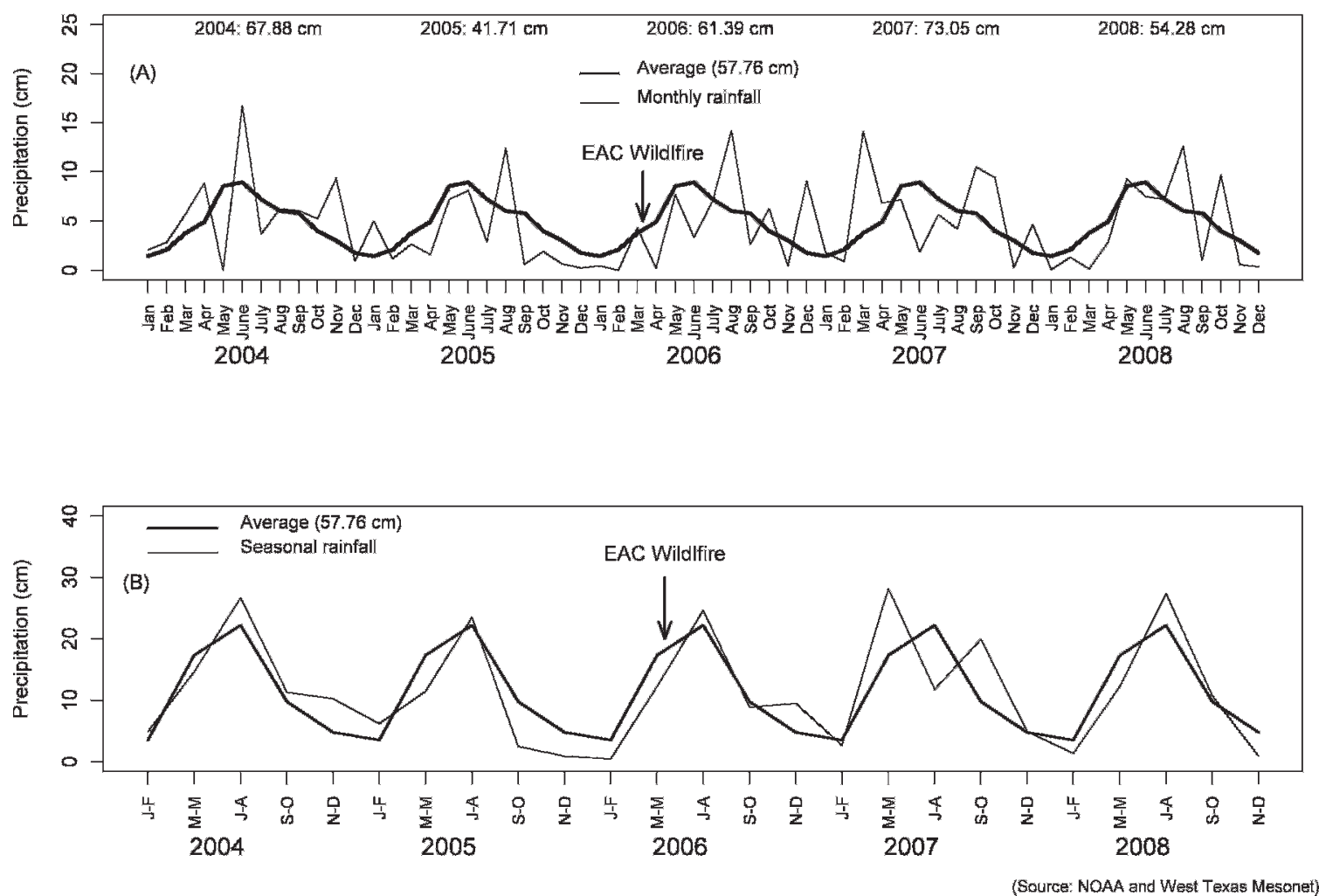

Figure 1. Monthly and seasonal precipitation (cm) from 2004 through 2008 in Pampa, Texas. Data are averages from the National Oceanic and Atmospheric Administration and West Texas Mesonet. Long-term average precipitation is shown by dark line. East Amarillo Complex (EAC) wildfires occurred in mid-March 2006.

Mixedland Slopes sites); quadrat locations were rerandomized each year. Biomass samples from each quadrat within an exclosure were dried at $60^{\circ} \mathrm{C}$ to constant weight, weighed to the nearest $0.1 \mathrm{~g}$, and averaged before statistical analysis. Grass and forb biomass are analyzed in this paper.

\section{Weather Records}

Closest weather stations to our study sites are McLean, Texas (Gray County), and Pampa, Texas (Gray County). Because rainfall data can be spatially variable, we averaged monthly and seasonal precipitation data from the National Oceanic and Atmospheric Administration (www.ncdc.noaa.gov/oa/ ncdc) and West Texas Mesonet (www.mesonet.ttu.edu) sites.

\section{Data Analysis}

A matched-pairs design is equivalent to a randomized block design where blocks are pairs of plots, and treatments are burned and nonburned areas. Because of lack of true replication on Deep Hardlands in 2006, only descriptive data are presented for 2006 responses. Some landowners practiced moderate season-long livestock grazing prior to the fire whereas others had rested pastures. Following the fire, some landowners enrolled in a USDA Natural Resources Conservation Service-sponsored livestock grazing deferral program from 15 March to 15 November or first frost 2006 and 2007, whereas others grazed cattle during the summer and fall of 2006 and thereafter. Finally, standing crop collected in 2006 from burned areas comprised entirely regrowth following the fire, whereas biomass harvested from nonburned areas was made up both of current year's growth and residual dry matter, the amount depending on grazing practices (Sims et al. 1978). However, standing crop data in 2007 and 2008 were collected inside our exclosures and thus included a combination of current year's growth as well as residual dry matter, regardless of burn treatment or landowner grazing practices. For these reasons, standing crop data were separated into two subsets for analysis: 1) data collected in 2006 (to assess wildfire effects on current year's growth and on total standing crop), and 2) data collected in 2007 and 2008 (total standing crop). For subset 2, fire effects, year-to-year differences, and their interaction were assessed with a repeated measures analysis. Biomass data were analyzed with a general linear mixed model (with blocks as a random effect); normality was assessed with the Shapiro-Wilk (1965) test. Mortality data were analyzed with a generalized linear mixed model with a logit link (McCulloch et al. 2008). For both analyses, main effects of burn treatment and year were analyzed when these effects did not interact.

\section{RESULTS}

\section{Precipitation}

Monthly rainfall patterns are important to show short-term pulses or deficits. It is equally important to consider rainfall in a seasonal context that corresponds to phenological patterns. Seasonal rainfall at Pampa, Texas (Fig. 1), and McLean, Texas 


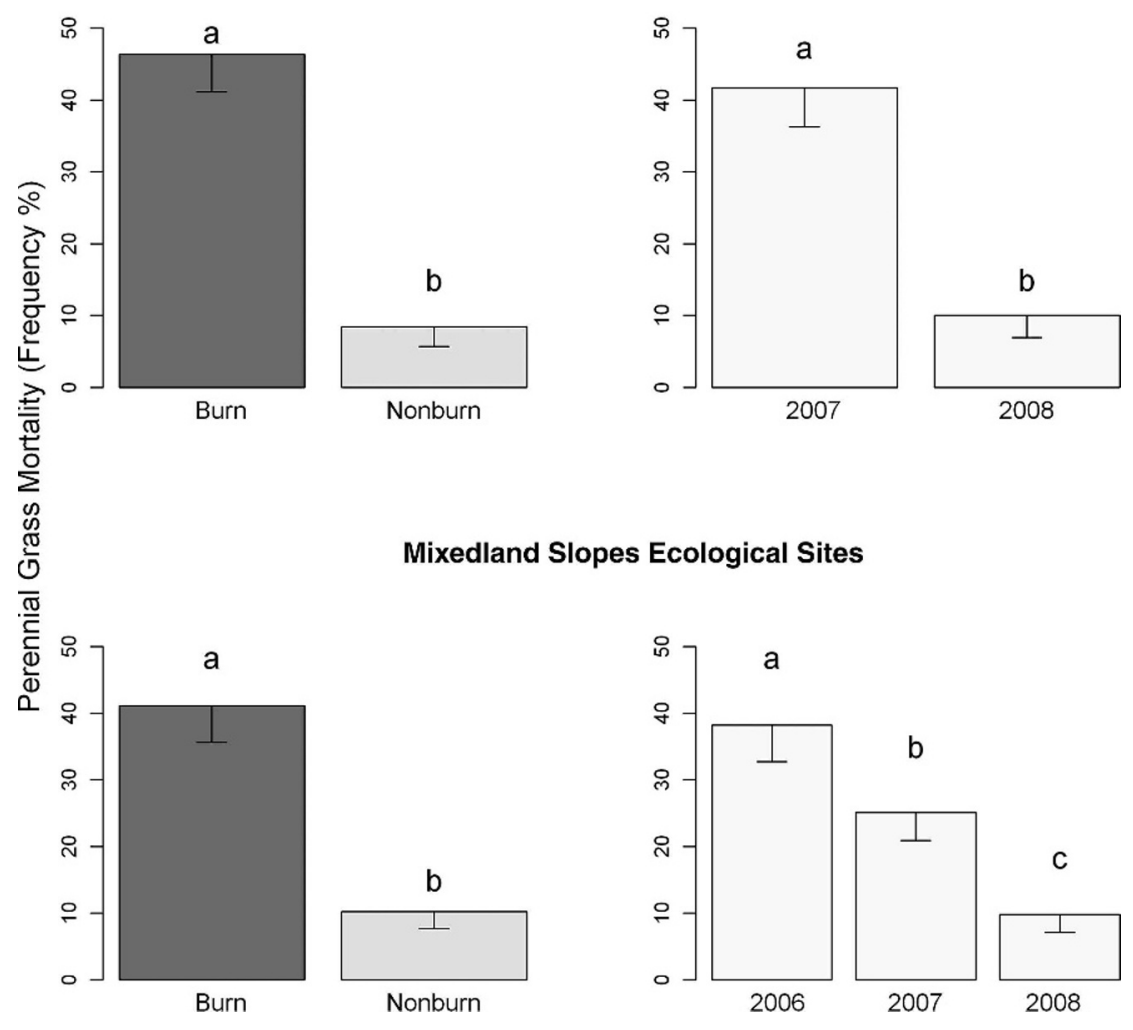

Figure 2. Perennial grass mortality frequency (\%) in burned and nonburned Deep Hardland and Mixedland Slopes ecological sites after 1 (2006), 2 (2007), and 3 (2008) growing seasons following the East Amarillo Complex wildfires. Percentages followed by the same lower case letter are not significantly different ( $P>0.05$, protected LSD test). For Mixedland Slopes sites, $r=5$ blocks, $n=250$ quadrats per treatment in 2006; $r=6$ blocks, $n=300$ quadrats per treatment in 2007 and 2008; for Deep Hardland sites, $r=1$ replication, $n=50$ quadrats per treatment in 2006 ; $r=6$ blocks, $n=300$ quadrats per treatment in 2007 and 2008.

(data not shown), was generally at or above average in 2004 ( 2 yr before the fire), at or below average in 2005 and 2006, and at or above average in 2007 and 2008 .

\section{Perennial Grass Mortality}

Fire and sampling year effects were similar at all quadrat sizes. Data from the $0.25-\mathrm{m}^{2}$ subquadrat are presented and discussed.

Mixedland Slopes Ecological Site. Frequency of mortality was higher in burned areas $(41.1 \%)$ than nonburned areas $(10.2 \%$; $\left.\mathrm{F}_{1,5}=26.37, P=0.0037\right)$, and these effects were independent of sampling date $\left(\mathrm{F}_{2,17}=0.01, P=0.9954\right.$; Fig. 2$)$. Mortality decreased each year $\left(\mathrm{F}_{2,17}=14.01, P=0.0003\right)$. Differences detected in 2007 and 2008 were similar regardless of whether data were based on 1) only those sites that were initially established in 2006 or 2) on all plots measured in 2007 and 2008.

Deep Hardland Ecological Site. Because of lack of true replication for data collected in 2006, only descriptive statistics are presented for this site. Frequency of mortality in burned and nonburned plots was $80.0 \%$ and $11.6 \%$, respectively. Addition of true replications in 2007 and 2008 allowed statistical comparisons. Frequency of mortality was higher in burned areas $(46.3 \%)$ than nonburned areas $\left(8.4 \% ; \mathrm{F}_{1,5}=24.35\right.$, $P=0.0043)$; these effects were independent of year $\left(\mathrm{F}_{1,10}=0.76, P=0.4038\right.$; Fig. 2$)$. Mortality decreased between years $\left(\mathrm{F}_{1,10}=18.99, P=0.0014\right)$.

\section{Peak Standing Crop}

Mixedland Slopes Ecological Site. In autumn 2006, standing crop in nonburned areas was composed of current year's growth as well as residual dry matter (standing litter) from previous years' growth. In contrast, standing crop in burned areas was entirely made up of current year's growth. In addition, variability in forb production was high not only in burned areas $\left(27.8 \pm 14.5 \mathrm{~g} \cdot \mathrm{m}^{-2}\right)$ but also in nonburned areas (current year's biomass was $5.9 \pm 4.5 \mathrm{~g} \cdot \mathrm{m}^{-2}$ ). Treatment comparisons were complicated by inclusion of previous years' residual dry matter and variability in forb production. For example, although total grass biomass was higher $\left(\mathrm{F}_{1,4}=10.64, P=0.0310\right)$ in nonburned areas (because of residual dry matter), current year's grass biomass was higher $\left(\mathrm{F}_{1,4}=27.62, P=0.0063\right)$ in burned areas (Fig. 3). Thus, wildfire stimulated grass production. However, there were no differences between burned and nonburned areas for either current forb production $\left(\mathrm{F}_{1,4}=2.15, P=0.2163\right)$ or total forb production $\left(\mathrm{F}_{1,4}=1.95\right.$, $P=0.2348)$. When grasses and forbs were combined, we found no differences $\left(\mathrm{F}_{1,4}=2.65, P=0.1789\right)$ in total standing crop between burned and nonburned areas, and a weak positive effect $\left(\mathrm{F}_{1,4}=6.1, P=0.0690\right)$ of wildfire on total current biomass production (Fig. 3).

In 2007 and 2008, there were no differences between years or treatments in their effects on grass, forb, or total standing crop $(P>0.2318$ for all tests; Fig. 4). Two of our study areas 

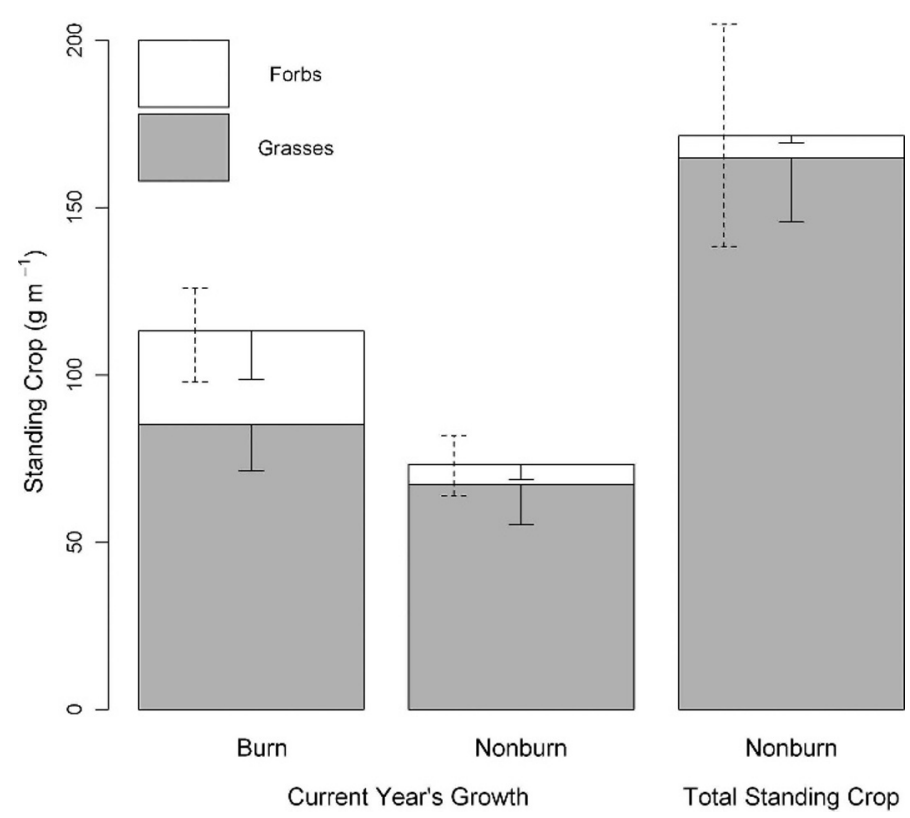

Figure 3. Peak standing crop $\left(\mathrm{g} \cdot \mathrm{m}^{-2}\right)$ in burned and nonburned Mixedland Slopes Ecological sites after 1 growing season (2006) following the East Amarillo Complex wildfires. Current year's production and total standing crop (current year's production + residual dry matter) are shown for grasses and forbs. One-sided, centered solid standard error bars are for individual grass and forb components; two-sided, offset dashed standard error bars are for total (grass + forbs) biomass ( $r=5$ blocks per treatment; $n=14$ and 12 quadrats for burned and nonburned treatments, respectively).

were on a ranch from which livestock had been removed $1 \mathrm{yr}$ prior to the wildfire, and three study areas had practiced season-long moderate cattle grazing prior to the wildfire. We found that the wildfire had largely similar results when 1) all study areas were analyzed, 2) only the grazed study areas were analyzed, and 3) only the nongrazed study areas were analyzed. Directions of differences were the same in these three analyses; however, fewer error degrees of freedom resulted in higher $P$ values, so that when only grazed areas were analyzed, fire effects on total grass production and current grass production were $\mathrm{F}_{1,2}=7.8, P=0.1078$ and $\mathrm{F}_{1,2}=19.24, P=0.0482$, respectively, with burned areas having higher production than nonburned areas. None of the effects were significant when only nongrazed areas were analyzed.

Deep Hardland Ecological Site. In 2006, standing crop was $761 \mathrm{~kg} \cdot \mathrm{ha}^{-1}$ in the burned site and $745 \mathrm{~kg} \cdot \mathrm{ha}^{-1}$ in the nonburned site (of which $236 \mathrm{~kg} \cdot \mathrm{ha}^{-1}$ was current year's growth). In 2007 and 2008 there were no differences in grasses, forbs, or total standing crop between treatments or years. There was no interaction between treatment and year for grasses $\left(\mathrm{F}_{1,10}=3.22, P=0.1028\right)$ or forbs $\left(\mathrm{F}_{1,10}=1.36\right.$, $P=0.2699$; Fig. 5). However, there was a weak interaction between treatment and year for total biomass $\left(\mathrm{F}_{1,10}=4.37\right.$, $P=0.0630):$ the difference between treatments diminished from 2007 to 2008 (Fig. 5).

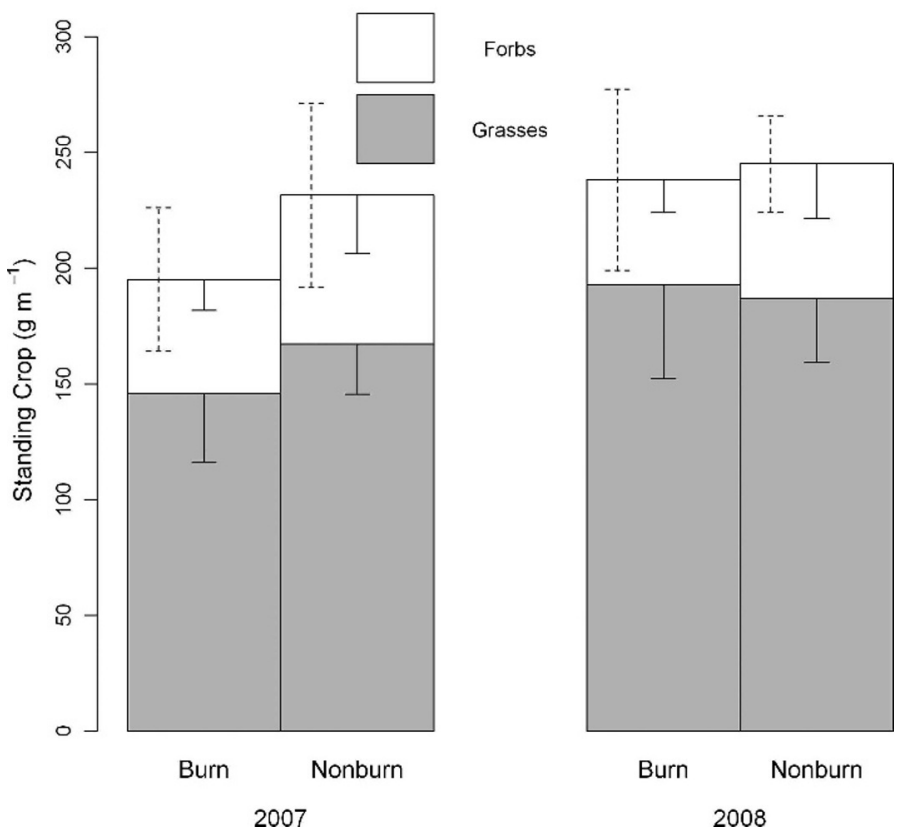

Figure 4. Peak standing crop (standing crop, $g \cdot \mathrm{m}^{-2}$ ) in burned and nonburned Mixedland Slopes Ecological sites 2 (2007) and 3 (2008) growing seasons following the East Amarillo Complex wildfires. Total standing crop (current year's production + residual dry matter) are shown for grasses and forbs. One-sided, centered solid standard error bars are for individual grass and forb components; two-sided, offset dashed standard error bars are for total (grass + forbs) biomass $(r=6$ blocks per treatment; $n=22$ and 23 quadrats for burned and nonburned treatments, respectively, in 2007; $n=12$ for burned and nonburned treatments in 2008).

\section{DISCUSSION}

\section{Perennial Grass Mortality}

Although we found higher mortality in burned sites, standing crop was minimally affected. Because fireline intensities and rates of spread are highly correlated (i.e., rate of spread is used in the calculation of fireline intensity; Clark 1983), it might be assumed that damage to vegetation caused by these wildfires would be correspondingly high. We explain our results by noting that there is little evidence that fire intensity is related to vegetation response in warm season grasses (Roberts et al. 1988) in the southern High Plains. Similarly, Armour et al. (1984) found that understory response in seral ponderosa pine (Pinus ponderosa Laws) forests was unrelated to flame length or fireline intensity. Although Bidwell and Engle (1992) found a weak $(P=0.07)$ multivariate response between fire behavior (rate of spread, fireline intensity, and heat per unit area) and components of aboveground herbaceous production in tallgrass prairies, this relationship apparently does not apply to shortand mixed-grass communities.

Plant mortality in the absence of fire can be caused by coverage/burial by grazing animal feces and activities of ants and small rodents (Fair et al. 2001) as well as unfavorable climatic conditions (e.g., Young 1956; Albertson and Tomanek 1965; Box 1967; Herbel et al. 1972) that interact with 
Deep Hardland Ecological Site

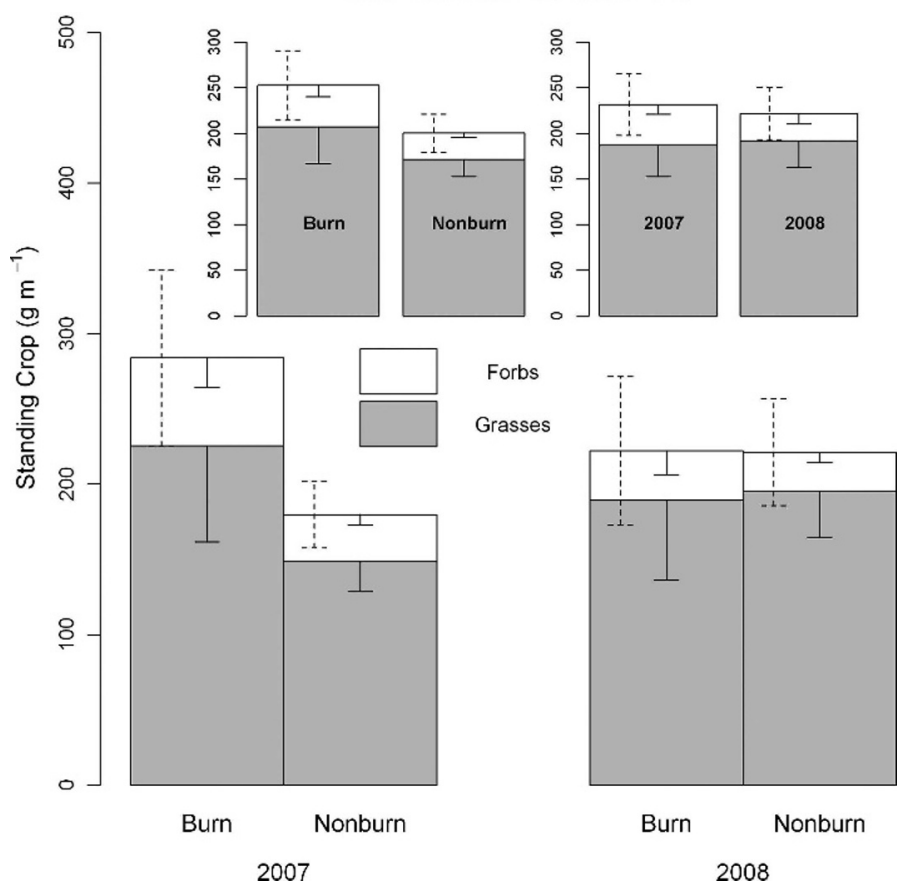

Figure 5. Peak standing crop (standing crop, $g \cdot \mathrm{m}^{-2}$ ) in burned and nonburned Deep Hardland Ecological sites 2 (2007) and 3 (2008) growing seasons following the East Amarillo Complex wildfires. Total standing crop (current year's production + residual dry matter) are shown for grasses and forbs. One-sided, centered solid standard error bars are for individual grass and forb components; two-sided, offset dashed standard error bars are for total (grass + forbs) biomass $(r=6$ blocks per treatment; $n=11$ and 12 quadrats for burned and nonburned treatments, respectively, in 2007; $n=12$ for burned and nonburned treatments in 2008).

management practices (Danckwerts and Stuart-Hill 1988; Vetter 2009). The size and frequency of these disturbances and their interaction with management are beyond the scope and control of this research. Thus, we assume that the mortality we observed in nonburned areas represents "natural" or "expected" plant mortality in the absence of fire, and higher mortality in burned areas was caused by the wildfires. It is likely that wildfire effects are inseparable from, and probably exacerbated by, management practices prior to, and weather conditions before and after, the wildfires.

In our study, mortality was quantified by relative frequency: When we report a mortality of $20 \%$, this means that there was a $20 \%$ chance that a randomly located sampling unit contained at least one dead perennial grass. Relative to differences in mortality between years, it is important to appreciate that quadrat locations were not permanently marked. Although some variability in results between years can be attributed to random relocation of quadrats each year, with a sample size of 50 quadrats per sampling site, we assumed that this effect was inconsequential.

An increase in mortality across years would be easy to interpret; however, we did not observe this response. We observed a decrease in mortality each sampling year in Mixedland Slopes and a decrease from 2007 to 2008 in Deep Hardlands. Several factors likely are involved. Seedlings, which may have established during the relatively wet months of 2004 and 2005, are especially susceptible to fire-induced mortality (e.g., Garnier and Dajoz 2001). The bases of seedlings that died in the fire might have been more noticeable in 2006 than in 2007 and 2008 if they had degraded or been blown away by the later sampling dates, resulting in lower measured mortality. It is also possible that plants that were judged as dead in 2006 (because of absence of green tissue) might actually have regenerated from underground bud zones and produced green tissue in 2007 or 2008, with the end result of lower measured mortality on later sampling dates (Young 1956; Fair et al. 2001; Munson and Lauenroth 2009).

Plant mortality in Mixedland Slopes and Deep Hardland sites was affected by burning and sampling time; these effects, however, acted independently of each other. Mortality was higher in burned areas than in nonburned areas. We attribute this to the combined effects of wildfires and harsh environmental conditions during the growing season following wildfires.

Not only was mortality higher in burned areas than in nonburned areas, but this effect was consistent from 2006 through 2008. This suggests that perennial grass mortality attributed to wildfire and subsequent growing conditions was measurable through three full growing seasons following wildfires. In view of the fact that growing season rainfall during 2007 and 2008 was generally at or above average, we conclude that 1) wildfires increased perennial grass mortality and 2) this effect was not short-term in duration. Furthermore, this conclusion applies both to Deep Hardland communities dominated by shortgrasses such as blue grama and buffalograss and to Mixedland Slopes communities dominated by midgrasses such as sideoats grama and little bluestem.

Mortality in 2006 was higher $(80 \%)$ in burned Deep Hardland sites than in Mixedland Slopes sites (60\%). Plant mortality caused by drought is related to soil texture, species, and management practices (Chamrad and Box 1965), and it is difficult to isolate these interacting factors. However, in our study areas Deep Hardland sites were dominated by blue grama and buffalograss; buffalograss was virtually absent from Mixedland Slopes sites. Buffalograss is not tolerant of drought (Albertson and Tomanek 1965), and thus study areas characterized by this species likely will show higher mortality because of its sensitivity. Because of the difficulty in defining individuals of stoloniferous plants we allow that this method of sampling plant mortality in these communities may have resulted in an overestimation of plant mortality frequency in the Deep Hardland sites. However, data were collected in both sites each year by the same individual, eliminating the possibility of differing interpretations and allowing for, at the very least, a relative comparison between years in Deep Hardland sites.

Even in nonburned sites, we observed a decrease in mortality from 2006 to 2008. With no data prior to 2006, we can only speculate on this trend. As indicated above, grass seedlings that may have established during wet periods in 2004 and 2005 might have died because of dry conditions during the six months prior to the wildfires or the three months following the fire. As in burned plots, these dead seedlings may have been more noticeable in 2006 than in 2007 or 2008, and fewer plants may have died during the wetter year of 2007. 


\section{Standing Crop}

There is considerable information available on fire effects on primary production in North American grasslands (e.g., Wright and Bailey 1982; DeBano et al. 1998; Scheintaub et al. 2009). Most of this work deals with prescribed fire. It is generally accepted that fire is important in maintaining tallgrass prairie by reducing woody species abundance and by enhancing herbaceous (mostly grass) biomass production. Less is known about wildfire effects in shortgrass plains communities (Scheintaub et al. 2009).

Mixedland Slopes Ecological Sites. We found that wildfires stimulated first-year grass production in Mixedland Slopes sites. Although this effect was numerically small, it was significant and is consistent with numerous reports in the literature (e.g., Wright and Bailey 1982 and references therein). Many mid- and tallgrasses respond to fire with enhanced tiller and biomass production, especially after early season burns (McMurphy and Anderson 1965; Owensby and Anderson 1967; Towne and Owensby 1984; Howe 1994; Pfeiffer and Steuter 1994; Coppedge et al. 1998; Towne and Kemp 2008). It is likely that adequate growing season precipitation enhanced our response. Biomass increases following fire are generally attributed to increased light availability to axillary buds at the plant base (McFarland and Mitchell 2000). Vogl (1974) reported that grass canopy removal activates latent primordial regions and thus stimulates new growth. Burning can result in warmer soil temperatures (Sharrow and Wright 1977; Hulbert 1988; Vermeire et al. 2005) and may suppress growth of competitors (Howe 1994). However, the stimulatory effect of these wildfires was short lived: biomass production in the second and third growing seasons following wildfires did not differ between burned and nonburned sites. Our results suggest that the effect of the EAC wildfires on biomass of Mixedland Slopes sites is similar to effects of prescribed fire on this vegetation. We conclude that 1 ) burned areas had less total (current + residual dry matter) grass biomass than nonburned areas one growing season following wildfire, 2) current year's grass production was higher in burned areas, and 3) total biomass (current + residual dry matter) was similar in burned and nonburned areas.

Deep Hardland Ecological Site. Our Deep Hardland sites were dominated by blue grama (generally as a sodformer on these sites) and buffalograss, with lesser amounts of hairy grama, sideoats grama, and perennial threeawns. Although lack of replication of burned treatments on these sites prevents statistical inference for first-year (2006) response, our harvested biomass samples suggested little burning effect. Further, second- and third-year data on replicated sites showed no difference between burned and nonburned areas.

A number of studies have shown that, depending on weather conditions, prescribed fire has little to no effect on shortgrass plains biomass production (Heirman and Wright 1974; Wright 1974; Castellano and Ansley 2007; Augustine and Milchunas, 2009; Scheintaub et al. 2009). In contrast, blue grama and buffalograss yield required two growing seasons to recover from a spring prescribed fire that was followed by a dry spring (Trlica and Schuster 1969), and Launchbaugh (1964) reported a 2-yr recovery time for these species following a spring wildfire during and after which rainfall was generally at or above normal. Brockway et al. (2002) reported strong declines in shortgrass biomass production following dormant and growing season prescribed fires that were followed by a wet spring, an average summer, and a wet fall.

Our results indicate that the EAC wildfires had minimal impact on standing crop of Deep Hardland ecological sites, a conclusion that partially supports the assessment of Scheintaub et al. (2009) that fire has neutral to negative effects in these grasslands. It is likely that favorable growing season rainfall conditions following the EAC wildfires contributed to this response.

\section{Synthesizing Mortality and Primary Production Results}

The EAC wildfires increased perennial grass mortality on both Mixedland Slopes and Deep Hardland sites. Although this effect was strongest during the first growing season following fire and decreased thereafter, it was nevertheless significant after three growing seasons. It might be expected that standing crop would be less in burned sites as a result of increased plant mortality. Our results, however, indicate that wildfire effects on standing crop depended on ecological site and were relatively short lived: on Mixedland Slopes, there was a modest increase in standing crop the first growing season following fire and no differences thereafter, whereas there was no effect on Deep Hardland sites.

Most studies (e.g., Aguilera and Lauenroth 1993, 1995; Richard and Redente 1995; Moffet 2003) of plant competition involving blue grama and buffalograss report interactions between and/or within these species (see Turner 1987; Coffin and Lauenroth 1991). Similarly, mid- and tall grasses in Mixedland Slopes sites commonly compete with each other (Wilson and Shay 1990; Smith et al. 1999). In the absence of management practices that involve nutrient or water addition, for a given ecological site and for a given mix of plant species there is an upper limit to ecosystem production in the absence of herbivory that is determined primarily by resource availability (e.g., Grime 2001; Daufresne and Hedin 2005), particularly available soil water (e.g., Sims et al. 1978; Sala et al. 1988). For example, the native plant community of Deep Hardland ecological sites is capable of producing 1183$2484 \mathrm{~kg} \cdot \mathrm{ha}^{-1}$ (depending on location site and environmental conditions; USDA 2008). Given the prevalence of competition in these communities, it is reasonable to suggest that the death of one or more individuals because of wildfire releases resources to surviving plants. For example, Aguilera and Lauenroth (1993) showed that gaps associated with death of adult blue grama plants had increased soil water, which enhanced seedling emergence; Zimmerman et al. (2008) extended these results to mortality caused by fire. It is likely that neighboring surviving plants benefit as well. Thus, the plant community as a whole reached its production potential in spite of the presence of dead plants. In an informal sense, surviving plants in our study sites may have "taken up the slack" following wildfires, and thus burned sites produced the same biomass as nonburned sites.

\section{IMPLICATIONS}

Despite the harsh environmental conditions leading up to the EAC wildfires and the extreme conditions experienced during 
the wildfire, this vegetation exhibited resilience that likely reflects the historical role of fire in this ecosystem. Our study sites represented a broad array of management practices both before and after the EAC wildfires. Incorporating this into the selection of our study sites, and analyzing our data to test these effects, was not possible. Consequently our results represent the average of these effects, and our overall finding of minimal wildfire effects suggests that management to ameliorate wildfire effects is unnecessary. In this study we failed to find a link between frequency of mortality and standing crop production. Finally, effects of these wildfires on standing crop were similar to prescribed fire effects reported in the literature.

\section{ACKNOWLEDGMENTS}

This work would not have been possible without the gracious cooperation of the following landowners: H. Boone, D. Burger, K. Burger, K. Flowers, S. Hale, J. Hutchinson, B. Ragsdale, J. Rhoades, J. Shaw, T. Thomas, and L. H. Webb. M. Ehrenreich, K. O’Rourke, M. Orr, C. Frey, K. Champlin, M. J. Beierle, D. Civitarese, G. Sorensen, and R. Weiser assisted with data collection and entry. Comments on an earlier version by the associate editor and reviewers greatly improved this paper. Additionally, Natural Resources Conservation Service and Texas Parks and Wildlife Department personnel were helpful in landowner contact information. This is publication no. T-9-1191, College of Agricultural Sciences and Natural Resources, Texas Tech University.

\section{LITERATURE CITED}

Aguilera, M. O., and W. K. Lauenroth. 1993. Seedling establishment in adult neighborhoods-intraspecific constraints in the regeneration of the bunchgrass Bouteloua gracilis. Journal of Ecology 81:253-261.

Aguilera, M. O., and W. K. LaUenRoth. 1995. Influence of gap disturbances and types of microsites on seedling establishment in Bouteloua gracilis. Journal of Ecology 83:87-97.

Alberston, F. W., and G. W. Tomanek. 1965. Vegetation changes during a 30-year period in grassland communities near Hays, Kansas. Ecology 46:714-720.

Anderson, R. C. 2006. Evolution and origin of the central grassland of North America: climate, fire, and mammalian grazers. Journal of the Torrey Botanical Club 133:626-647.

Ansley, R. J., And M. J. CAstellano. 2007. Texas wintergrass and buffalograss response to seasonal fires and clipping. Rangeland Ecology \& Management 60:154-164.

Armour, C. D., S. C. Bunting, and L. F. Neuenschwander. 1984. Fire intensity effects on the understory in ponderosa pine forests. Journal of Range Management $37: 44-49$

Augustine, D. J., and D. G. Milchunas. 2009. Vegetation responses to prescribed burning of grazed shortgrass steppe. Rangeland Ecology \& Management 62:89-97.

AxelRod, D. I. 1985. Rise of the grassland biome, central North America. Botanical Review 51:163-201.

Benson, E. J., D. C. Hartnett, and K. H. Mann. 2004. Belowground bud banks and meristem limitation in tallgrass prairie plant populations. American Journal of Botany 91:416-421.

BidweLl, T. G., ANd D. M. Engle. 1992. Relationship of fire behavior to tallgrass prairie herbage production. Journal of Range Management 45:579-584.

Box, T. W. 1967. Influence of drought and grazing on mortality of five west Texas grasses. Ecology 48:654-656.

Briske, D. D., AND J. H. Richards. 1995. Plant responses to defoliation: a physiologic, morphologic, and demographic perspective. In: D. J. Bedunah and R. E. Sosebee [EDS.]. Wildland plants: physiological ecology and developmental morphology. Denver, CO, USA: Society of Range Management. p. $635-710$.
Brockway, D. G., R. G. Gatewood, and R. B. Paris. 2002. Restoring fire as an ecological process in shortgrass prairie ecosystems: initial effects of prescribed burning during the dormant and growing seasons. Journal of Environmental Management 65:135-152.

Castellano, M. J., and R. J. Ansley. 2007. Fire season and simulated grazing differentially affect the stability and drought resilience of a $\mathrm{C}_{4}$ bunchgrass, $\mathrm{C}_{3}$ bunchgrass, and $\mathrm{C}_{4}$ lawngrass. Journal of Arid Environments 69:375-384.

Chamrad, A. D., and T. W. Box. 1965. Drought-associated mortality of range grasses in South Texas. Ecology 46:780-785.

CLARK, R. G. 1983. Threshold requirements for fire spread in grassland fuels. [dissertation]. Lubbock, TX, USA: Texas Tech University. 72 p.

Coffin, D. P., and W. K. Lauenroth. 1988. The effects of disturbance size and frequency on a shortgrass plant community. Ecology 69:1609-1617.

Coffin, D. P., and W. K. Lauenroth. 1991. Effects of competition on spatial distribution of roots of blue grama. Journal of Range Management 44:68-71.

Coppedge, B. R., D. M. Engle, C. S. Toepfer, and J. H. Shaw. 1998. Effects of seasonal fire, bison grazing and climatic variation on tallgrass prairie vegetation. Plant Ecology 139:235-246.

DAHL, B. E. 1995. Developmental morphology of plants. In: D. J. Bedunah and R. E. Sosebee [EDS.]. Wildland plants: physiological ecology and developmental morphology. Denver, C0, USA: Society of Range Management. p. 22-58.

Danckwerts, J. E., and G. C. Stuart-Hill. 1988. The effect of severe drought and management after drought on the mortality and recovery of semi-arid grassveld. African Journal of Range and Forage Science 5:218-222.

Daufresne, T., and L. 0. Hedin. 2005. Plant coexistence depends on ecosystem nutrient cycles: extension of the resource-ratio theory. Proceedings of the National Academy of Sciences 102:9212-9217.

Debano, L. F., D. G. Neary, and P. F. Ffollott. 1998. Fire's effects on ecosystems. New York, NY, USA: John Wiley. 333 p.

Doust, A. 2007. Architectural evolution and its implications in domestication in grasses. Annals of Botany 100:941-950.

FalR, J., W. K. Lauenroth, and D. P. Coffin. 1999. Demography of Bouteloua gracilis in a mixed prairie: analysis of genets and individuals. Journal of Ecology 87:233-243.

FalR, J. L., D. P. C. Peters, and W. K. Lauenroth. 2001. Response of individual Bouteloua gracilis (Gramineae) plants and tillers to small disturbances. American Midland Naturalist 145:147-158.

Garnier, L. K. M., And I. Dajoz. 2001. The influence of fire on the demography of a dominant grass species of West African Savannas, Hyparrhenia dyplandra. Journal of Ecology 89:200-208.

Grime, J. P. 2001. Plant strategies, vegetation processes and ecosystem properties. 2nd ed. Chichester, England: John Wiley and Sons. $417 \mathrm{p}$.

Heirman, A. L., And H. A. Wright. 1974. Fire in medium fuels of west Texas. Journal of Range Management 26:331-335.

Herbel, C. H., F. N. Ares, and R. A. Wright. 1972. Drought effects on a semidesert grassland range. Ecology 53:1084-1093.

HowE, H. F. 1994. Response of early- and late-flowering plants to fire season in experimental prairies. Ecological Applications 4:121-133.

Hulbert, L. C. 1988. Causes of fire effects in tallgrass prairie. Ecology 69:46-58.

Keeley, J. E., and P. W. Rundel. 2005. Fire and the Miocene expansion of $\mathrm{C}_{4}$ grasslands. Ecology Letters 8:683-690.

KLIMESOVA, J., AND L. KLIMES. 2007. Bud banks and their role in vegetative regenerationa literature review and proposal for simple classification and assessment. Perspectives in Plant Ecology, Evolution and Systematics 8:115-129.

Launchbaugh, J. L. 1964. Effects of early spring burning on yields of native vegetation. Journal of Range Management 17:5-7.

McCulloch, C. E., S. R. Searle, and J. M. Neuhaus. 2008. Generalized, linear and mixed models. 2nd ed. New York, NY, USA: John Wiley and Sons. $384 \mathrm{p}$.

McFarland, J. B., and R. Mitchell. 2000. Fire effects on weeping lovegrass tiller density and demographics. Agronomy Journal 92:42-47.

McMurphy, W. E., And K. L. Anderson. 1965. Burning Flint Hills range. Journal of Range Management 18:265-269.

Moffet, C. A. 2003. Competition among blue grama and buffalograss ecotypes: effects of soil and past neighbor interactions [dissertation]. Lubbock, TX, USA: Texas Tech University. 299 p. 
Munson, S. M., and W. K. Lauenroth. 2009. Plant population and community responses to removal of the dominant species. Journal of Vegetation Science 20:1-9.

National Interagency Fire Center. 2010. National Interagency Fire Center, fire information—wildland fire statistics. Available at: http://www.nifc.gov/fire_ info/nfn.htm. Accessed 15 February 2010.

Owensby, C. E., And K. L. Anderson. 1967. Yield responses to time of burning in the Kansas Flint Hills. Journal of Range Management 20:12-16.

Pfeiffer, K. E., and A. A. Steuter. 1994. Preliminary response of Sandhills prairie to fire and bison grazing. Journal of Range Management 47:395-397.

Richard, C. E., and E. F. Redente. 1995. Nitrogen and phosphorus effects on blue grama and buffalograss interactions. Journal of Range Management 48:417-422.

Roberts, F. H., C. M. Britton, D. B. Wester, and R. G. Clark. 1988. Fire effects on tobosagrass and weeping lovegrass. Journal of Range Management 41:407-409.

Sala, 0. E., W. J. Parton, L. A. Joyce, and W. K. Lauenroth. 1988. Primary production of the central grassland region of the United States. Ecology 69:40-45.

Scheintaub, M. R., J. D. Derner, E. F. Kelly, and A. K. Knapp. 2009. Response of the shortgrass steppe plant community to fire. Journal of Arid Environments 73:1136-1143.

Scurlock, J. M. 0., K. Johnson, and R. J. OLson. 2002. Estimating net primary productivity from grassland biomass dynamics measurements. Global Change Biology 8:736-753.

ShapIRO, S. S., AND M. B. WILK. 1965. An analysis of variance test for normality (complete samples). Biometrika 52:591-611.

Sharrow, S. H., AND H. A. Wright. 1977. Effects of fire, ash, and litter on soil nitrate, temperature, moisture and Tobosa-grass production in rolling plains. Journal of Range Management 30:266-270.

Sims, P. L., J. S. Singh, and W. K. Lauenroth. 1978. The structure and function of ten western North American grasslands. I: abiotic and vegetational characteristics. Journal of Ecology 66:251-285.

Smith, M. D., D. C. Harnett, and G. W. T. WILSON. 1999. Interacting influence of mycorrhizal symbiosis and competition on plant diversity in tallgrass prairie. Oecologia 121:574-582.

Stromberg, C. A. E. 2005. Decoupled taxonomic radiation and ecological expansion of open-habitat grasses in the Cenozoic of North America. Proceedings of the National Academy of Sciences 102:11980-11984.

ToWNE, E. G., AND K. E. KEMP. 2008. Long-term response patterns of tallgrass prairie to frequent summer burning. Rangeland Ecology \& Management 61: 509-520.
Towne, E. G., And C. E. OwensBy. 1984. Long-term effects of annual burning at different dates in ungrazed Kansas tallgrass prairie. Journal of Range Management 37:392-397.

TrLICA, M. J., AND J. L. Schuster. 1969. Effects of fire on grasses of the Texas High Plains. Journal of Range Management 22:329-333.

TURneR, S. J. 1987. Competition and coexistence between two C4 grasses of the shortgrass steppe [dissertation]. Ft. Collins, CO, USA: Colorado State University. $202 \mathrm{p}$.

[USDA] US Department of Agriculture. 2008. Ecological Site Description, Natural Resources Conservation Service. Available at: http://esis.sc.egov.usda.gov/ esis_report. Accessed 16 July 2009.

Vermeire, L. T., D. B. Wester, R. B. Mitchell, and S. D. Fuhlendorf. 2005. Fire and grazing effects on wind erosion, soil water content, and soil temperature. Journal of Environmental Quality 34:1559-1565.

VETTER, S. 2009. Drought, change and resilience in South Africa's arid and semiarid rangelands. South African Journal of Science 105:29-33.

VogL, R. J. 1974. Effects of fire on grasslands. In: T. T. Kozlowski and C. E. Ahlgren [EDS.]. Fire and ecosystems. New York, NY, USA: Academic Press. p. 139-194.

Westerling, A. L., H. G. Hidalgo, D. R. Cayan, and T. W. Swetnam. 2006. Warming and earlier spring increase western U.S. forest wildfire activity. Science 313:940-943.

Wiens, J. A., and K. R. Parker. 1995. Analyzing the effects of accidental environmental impacts: approaches and assumptions. Ecological Applications 5:1069-1083.

Wilson, S. D., AND J. M. Shay. 1990. Competition, fire and nutrients in a mixedgrass prairie. Ecology 71:1959-1967.

WriGht, H. A. 1974. Effect of fire on southern mixed prairie grasses. Journal of Range Management 27:417-419.

Wright, H. A., AND A. W. Balley. 1982. Fire ecology: United States and southern Canada. New York, NY, USA: John Wiley and Sons. 501 p.

Young, V. A. 1956. The effects of the 1949-1956 drought on the ranges of Texas. Journal of Range Management 9:139-142.

Zane, D., J. Henry, C. Lindley, P. W. Pendergrass, D. Galloway, T. Spencer, and M. Stanley. 2006. Surveillance of mortality during the Texas Panhandle wildfires (March 2006). Austin, TX, USA: Texas Department of State Health Services, and Texas Forest Service. 7 p.

Zimmerman, J., S. I. Higgins, V. Grimm, J. Hoffmann, T. Münkemüller, and A. Linstädter. 2008. Recruitment filters in a perennial grassland: the interactive roles of fire, competitors, moisture and seed availability. Journal of Ecology 96: 1033-1044. 